\title{
Pengaruh Terapi Zikir Terhadap Tingkat Kecemasan Pasien Pre Operasi Sectio Caesarea Di RSUD Dr. H. Moch. Ansari Saleh Banjarmasin 2018
}

\author{
Syufian Noor \\ Sekolah Tinggi Ilmu Kesehatan Cahaya Bangsa Banjarmasin \\ Program Studi Ilmu Keperawatan \\ syufiannuur@,gmail.com
}

DOI: https://doi.org/10.33859/dksm.v10i2.507

\begin{abstract}
Abstrak
Latar belakang: Sectio Caesarea yaitu salah satu tindakan operasi untuk mengeluarkan bayi dengan melakukan insisi atau pemotongan pada kulit, otot perut, serta rahim ibu. Tindakan operasi sectio caesarea dengan berbagai komplikasi dapat menimbulkan kecemasan pada pasien. Intervensi keperawatan dalam upaya menurunkan tingkat kecemasan secara non-farmakologi yaitu melalui terapi zikir.

Tujuan: untuk mengetahui pengaruh terapi zikir terhadap tingkat kecemasan pasien pre operasi sectio caesarea Di RSUD Dr. H. Moch. Ansari Saleh Banjarmasin 2018.

Metode: penelitian ini merupakan penelitian kuantitatif menggunakan rancangan quasi eksperimen dengan pendekatan one grup pra-post test design tanpa kelompok kontrol. Sampel dalam penelitian ini berjumlah 35 pasien pre operasi sectio caesarea di Ruang Nifas dengan teknik pengambilan sampel adalah purposive sampling menggunakan uji paired sample t-tes.

Hasil: hasil analisis uji paired sample t-tes didapatkan $p$ value $=0,000 \leq 0,05$ sehingga dapat ditarik kesimpulan ada pengaruh yang signifikan antara terapi zikir terhadap tingkat kecemasan pasien pre operasi sectio caesarea di RSUD Dr. H. Moch. Ansari Saleh Banjarmasin 2018.

Simpulan: bagi pasien yang akan menjalani persalinan melalui operasi sectio caesarea terapi zikir dengan kalimat tasbih, tahmid dan takbir masing - masing 33x dibaca berulang selama 10 menit dapat menurunkan tingkat kecemasan.
\end{abstract}

Kata kunci: Terapi zikir, tingkat kecemasan, pasien pre operasi sectio caesarea 
Background: sectio Caesarea is one of the surgical actions to remove the baby by doing incision or cutting on the skin, abdominal muscles, and mother's womb. The action of Sectio Caesarea operations with various complications can cause anxiety in patients. Nursing intervention in the effort to lower the level of non-pharmacological anxiety through zikr therapy.

Purpose: To determine the effect of remembrance therapy on the anxiety level of patients preoperative sectio Caesarea at Dr. H. Moch Hospital. Ansari Saleh Banjarmasin 2018.

Method: PEnelitian is quantitative research using the design of the quasi experiment with one group pre-post test design approach without control group. The sample in this study amounted to 35 patients pre-operative sectio Caesarea in the Nifas room with sampling techniques being purposive sampling Using Test paired sample T-Tests.

Results: Hacyl test Analysis paired sample T-tes obtained $p$ value $=0.000 \leq 0.05$ so that it can be concluded there is a significant influence between the therapy of remembrance of the anxiety level of patients pre-operative sectio Caesarea di Rsud Dr. h. Moch. Ansari Saleh Banjarmasin 2018.

Conclusion: patients who will undergo childbirth through the operation of Sectio Caesarea zikr therapy with sentence Tasbih, Tahmid and Takbeer respectively $33 \mathrm{x}$ read repeatedly for 10 minutes can lower the level of anxiety.

Keywords: dhikr therapy, anxiety level, patient pre operativeectio Caesarea

\section{Pendahuluan}

Sectio caesarea yaitu salah satu

tindakan operasi untuk mengeluarkan bayi

dengan melakukan insisi atau pemotongan

pada kulit, otot perut, serta rahim ibu. Sectio

caesarea umumnya dilakukan ketika proses

persalinan normal melalui vagina tidak

memungkinkan atau karena adanya indikasi

medis maupun non-medis (Suririnah, 2012).

Operasi seperti sectio caesarea

merupakan salah satu bentuk intervensi medis

terencana yang biasanya berlangsung lama.

Tindakan operasi sectio caesarea dengan berbagai komplikasinya dapat menimbulkan kecemasan pada pasien (Pawatte, Pali \& Opod, 2013).

Kecemasan merupakan pengalaman subjektif dari individu dan tidak dapat diobservasi secara lansung serta merupakan suatu keadaan emosi tanpa objek spesifik (Suliswati, 2013).

Berdasarkan data dari (WHO, 2013) menetapkan standar rata-rata sectio caesarea sebuah Negara adalah sekitar 5-15\% per 1000 kelahiran di dunia, rumah sakit pemerintah 
Dinamika Kesehatan Jurnal Kebidanan dan Keperawatan Vol 10 No. 22019 ( ISSN: 2086-3454 EISSN: 2549-4058) url: http://ojs.dinamikakesehatan.unism.ac.id DOI: https://doi.org/10.33859/dksm.v10i2 Pengaruh Terapi Zikir Terhadap Tingkat Kecemasan Pasien Pre Operasi Sectio Caesarea Di RSUD Dr. H. Moch. Ansari Saleh Banjarmasin 2018

dengan rata - rata $11 \%$ sementara rumah sakit

swasta bisa lebih dari 30\%. Menurut WHO peningkatan persalinan dengan sectio caesarea di seluruh Negara terjadi selama 2007-2008 yaitu 110.000 per kelahiran di seluruh Asia. Demikian juga di Taiwan, angka kelahiran dengan sectio caesarea menunjukan angka semakin pesat yakni 37,6\% pada tahun 2012 .

Di Indonesia persalinan metode sectio caesarea bukan merupakan hal yang baru lagi.

Menurut Data Survei Demografi dan Kesehatan Indonesia (SDKI) 2012, angka kejadian sectio caesarea di Indonesia 921.000 dari 4.039.000 persalinan atau sekitar 22,8\% dari seluruh persalinan.

Dari data tiga tahun terakhir di RSUD

Dr. H. Moch Ansari Saleh Banjarmasin diketahui sebanyak 1.328 yang melahirkan melalui sectio caesarea pada tahun 2015 sebanyak 128, tahun 2016 sebanyak 751, dan tahun 2017 sebanyak 449 kelahiran.

Hasil studi pendahuluan yang dilakukan peneliti pada tanggal 26 maret - 7 April 2018 di RSUD Dr. H. Moch. Ansari Saleh Banjarmasin berdasarkan hasil wawancara dengan menggunakan skala kecemasan HARS (hamilton anxiety rating scale) dengan 17 pasien yang akan melakukan operasi sectio caesarea terdapat 1 orang memiliki tingkat kecemasan kategori berat, 8 orang dalam kategori sedang, 5 orang dalam kategori ringan, dan 3 orang tidak merasa cemas.

Salah satu pendekatan keyakinan spiritual dalam agama Islam yaitu dengan teknik mengingat Allah atau berzikir. Zikir merupakan bentuk dari unsur spiritual dan religius. Bacaan zikir mampu menenangkan, membangkitkan percaya diri, kekuatan, perasaan aman, tentram, dan memberikan perasaan bahagia (Subandi, 2014).

Berdasarkan uraian diatas, maka peneliti sudah melakukan penelitian pada pasien pre operasi sectio caesarea tentang Pengaruh Terapi Zikir Terhadap Tingkat Kecemasan Pasien Pre Operasi Sectio Caesarea Di RSUD Dr. H. Moch. Ansari Saleh Banjarmasin. 
Dinamika Kesehatan Jurnal Kebidanan dan Keperawatan Vol 10 No. 22019 ( ISSN: 2086-3454 EISSN: 2549-4058)

url: http://ojs.dinamikakesehatan.unism.ac.id DOI: https://doi.org/10.33859/dksm.v10i2

Pengaruh Terapi Zikir Terhadap Tingkat Kecemasan Pasien Pre Operasi Sectio Caesarea

Di RSUD Dr. H. Moch. Ansari Saleh Banjarmasin 2018

\section{Metode}

Penelitian ini merupakan penelitian kuantitatif menggunakan rancangan quasi eksperimen dengan pendekatan one group prapost test design tanpa kelompok kontrol.

Metode pengambilan sampel menggunakan purposive sampling, jumlah responden sebanyak 35 responden dengan kriteria inklusi dan eklusi yang telah ditetapkan.

Penelitian dilakukan selama 3 minggu, pengumpulan data yang digunakan adalah lembar kuisioner kecemasan HARS (Hamilton Anxiety Rating Scale) dengan karakteristik responden terdiri dari usia, pendidikan dan pekerjaan.

\section{Hasil}

1. Gambaran Umum Lokasi Penelitian

RSUD Dr. H. Moch Ansari Saleh Banjarmasin merupakan Rumah Sakit Umum Daerah kelas B yang berlokasi di J1. Brigjend Hasan Basry No. 1 Banjarmasin.
2. Karakteristik Responden

a. Usia

\begin{tabular}{ccc}
\hline Usia & $(\mathrm{n})$ & $(\%)$ \\
\hline $25-30$ & 17 & 48,6 \\
$31-35$ & 11 & 31,4 \\
$36-40$ & 4 & 11,4 \\
$41-45$ & 3 & 8,6 \\
\hline Total & 35 & 100 \\
\hline
\end{tabular}

b. Pendidikan

\begin{tabular}{ccc}
\hline Pendidikan & $(\mathrm{n})$ & $(\%)$ \\
\hline SD & 6 & 17,1 \\
SMP & 13 & 37,1 \\
SMA & 12 & 34,3 \\
Sarjana & 4 & 11,4 \\
\hline Total & 35 & 100 \\
\hline
\end{tabular}

c. Pekerjaan

\begin{tabular}{ccc}
\hline Pekerjaan & (n) & $(\%)$ \\
\hline IRT & 28 & 80 \\
PNS & 1 & 2,9 \\
Wiraswasta & 6 & 17,1 \\
\hline Total & 35 & 100 \\
\hline
\end{tabular}

3. Analisa Univariat

a. Tingkat Kecemasan Responden Sebelum Dilakukan Terapi Zikir Pada Pasien Pre Operasi Sectio Caesarea Di RSUD Dr. H. Moch Ansari Saleh Banjarmasin

\begin{tabular}{lcc}
\hline \multicolumn{1}{c}{ Tingkat Kecemasan } & $(\mathrm{n})$ & $(\%)$ \\
\hline Tidak cemas & 4 & 11,4 \\
Kecemasan ringan & 19 & 54,3 \\
Kecemasan sedang & 12 & 34,4 \\
Kecemasan berat & 0 & 0 \\
\hline \multicolumn{1}{c}{ Total } & 35 & 100 \\
\hline
\end{tabular}

b. Tingkat Kecemasan Responden Sesudah Dilakukan Terapi Zikir Pada Pasien Pre Operasi Sectio Caesarea Di RSUD Dr. H. Moch Ansari Saleh Banjarmasin

\begin{tabular}{lcc}
\hline \multicolumn{1}{c}{ Tingkat Kecemasan } & $(\mathrm{n})$ & $(\%)$ \\
\hline Tidak cemas & 11 & 31,4 \\
Kecemasan ringan & 16 & 45,8 \\
Kecemasan sedang & 8 & 22,9 \\
Kecemasan berat & 0 & 0 \\
\hline \multicolumn{1}{c}{ Total } & 35 & 100 \\
\hline
\end{tabular}

\begin{tabular}{lccccc} 
4. Analisa Bivariat & & & & \\
\hline Variabel & Mean & Median & SD & T & $\begin{array}{c}\text { Sig. } \\
(2- \\
\text { taile } \\
\text { d) }\end{array}$ \\
\hline Pre & 13,54 & 13.00 & 5,67 & & \\
Post & 9,77 & & 4.83 & 32 & 0.00 \\
Selisih & 3,77 & 8.00 & 0,84 & & \\
\hline
\end{tabular}


Dinamika Kesehatan Jurnal Kebidanan dan Keperawatan Vol 10 No. 22019 ( ISSN: 2086-3454 EISSN: 2549-4058)

url: http://ojs.dinamikakesehatan.unism.ac.id DOI: https://doi.org/10.33859/dksm.v10i2

Pengaruh Terapi Zikir Terhadap Tingkat Kecemasan Pasien Pre Operasi Sectio Caesarea

Di RSUD Dr. H. Moch. Ansari Saleh Banjarmasin 2018

\section{Pembahasan}

1. Analisis Berdasarkan Karakteristik

Berdasarkan tabel usia responden dapat dilihat bahwa yang paling cenderung mengalami kecemasan adalah usia 25-30 tahun yaitu sebanyak 17 orang $(48,6 \%)$.

$$
\text { Menurut Stuart (2012) usia }
$$

dapat mempengaruhi psikologi individu. Semakin tinggi usia seseorang maka semakin baik tingkat kematangan emosionalnya serta kemampuan dalam menghadapi berbagai persoalan dalam kehidupan. Sejalan dengan teori Notoatmojo (2010) mengatakan pada usia yang semakin tua maka seseorang semakin banyak pengalamannya sehingga pengetahuan semakin bertambah. Karena pengetahuan banyak maka seseorang akan lebih siap dalam menghadapi sesuatu.

Berdasarkan tabel pendidikan responden dapat dilihat bahwa pendidikan responden SD sebanyak 6 orang $(17,1 \%)$.

Menurut Stuart (2012) tingkat pendidikan yang rendah akan menyebabkan individu mudah mengalami kecemasan. Semakin tingkat pendidikannya tinggi akan mempengaruhi kemampuan berfikirnya.

Berdasarkan tabel pekerjaan responden dapat dilihat bahwa pekerjaan responden IRT sebanyak 28 orang $(80 \%)$.

Lingkungan pekerjaan dapat menjadikan seseorang memperoleh pengalaman baik secara lansung dan tidak lansung (Mubarak, 2011).

Menurut Stuart dukungan sosial dan lingkungan sebagai sumber koping, dimana kehadiran orang lain dapat membantu mengurangi kecemasan dan lingkungan yang mempengaruhi area berpikir seseorang. 
Dinamika Kesehatan Jurnal Kebidanan dan Keperawatan Vol 10 No. 22019 ( ISSN: 2086-3454 EISSN: 2549-4058)

url: http://ojs.dinamikakesehatan.unism.ac.id DOI: https://doi.org/10.33859/dksm.v10i2

Pengaruh Terapi Zikir Terhadap Tingkat Kecemasan Pasien Pre Operasi Sectio Caesarea

Di RSUD Dr. H. Moch. Ansari Saleh Banjarmasin 2018

2. Analisis Tingkat Kecemasan

Responden Sebelum Dilakukan Terapi

Zikir Pada Pasien Pre Operasi Sectio

Caesarea Di RSUD Dr. H. Moch

Ansari Saleh Banjarmasin

Pada tabel analisa univariat

menunjukan bahwa tingkat kecemasan

responden sebelum dilakukan terapi

zikir adalah yang tidak mengalami

kecemasan 4 orang $(11,4 \%)$,

kecemasan ringan 19 orang (54,3\%),

kecemasan sedang 12 orang $(34,4 \%)$

dan tidak ditemukan pasien yang

mengalami kecemasan berat.

Kecemasan

adalah

kekhawatiran yang tidak jelas dan menyebar, yang berkaitan dengan perasaan tidak pasti dan tidak berdaya (Stuart, 2012).

Menurut Stuart (2012)

mekanisme koping digunakan individu

ketika mengalami kecemasan.

Ketidakmampuan dalam mengatasi

kecemasan secara konstruktif sebagai

penyebab terjadinya perilaku patologis.
Faktor yang mempengaruhi

kecemasan pasien tidak bisa

dikendalikan sepenuhnya, teori

perilaku menyatakan bahwa

kecemasan merupakan hasil frustasi

akibat berbagai hal yang

mempengaruhi individu dalam

mencapai tujuan yang di inginkan.

3. Analisis Tingkat Kecemasan

Responden Sesudah Dilakukan Terapi

Zikir Pada Pasien Pre Operasi Sectio

Caesarea Di RSUD Dr. H. Moch

Ansari Saleh Banjarmasin

Pada tabel analisa univariat menunjukan bahwa tingkat tingkat kecemasan responden sesudah dilakukan terapi zikir adalah ibu yang tidak mengalami kecemasan 11 orang $(31,4 \%)$, kecemasan ringan 16 orang (45,8\%), kecemasan sedang 8 orang $(22,9 \%)$ dan tidak ditemukan pasien yang mengalami kecemasan berat.

Dari tabel tersebut dapat dilihat bahwa hasil setelah diberikan terapi zikir bahwa ada peebedaan atau 
Dinamika Kesehatan Jurnal Kebidanan dan Keperawatan Vol 10 No. 22019 ( ISSN: 2086-3454 EISSN: 2549-4058)

url: http://ojs.dinamikakesehatan.unism.ac.id DOI: https://doi.org/10.33859/dksm.v10i2

Pengaruh Terapi Zikir Terhadap Tingkat Kecemasan Pasien Pre Operasi Sectio Caesarea

Di RSUD Dr. H. Moch. Ansari Saleh Banjarmasin 2018

penurunan tingkat kecemasan sebelum

dilakukan terapi zikir.

Tingkat kecemasan adalah

gambaran yang dialami oleh individu, pengukuran dan identifikasi dengan tingkat kecemasan meliputi kecemasan ringan, kecemasan sedang, kecemasan berat dan panik (Dalami, 2012).

$$
\text { Bacaan zikir mampu }
$$

menenangkan, membangkitkan

percaya diri, kekuatan, perasaan aman,

tentram, dan memberikan perasaan

bahagia (Subandi, 2014). Zikir secara

maksimal memiliki banyak manfaat

bagi manusia yang berkaitan dengan

kondisi kesehatan fisik antara lain

menghilangkan depresi, kesulitan,

kegundahan dan kecemasan (Zainul, 2015).

Dari hasil penelitian didapat responden sebagian besar mengalami penurunan skor kecemasan setelah dilakukan terapi zikir.

4. Pengaruh Terapi Zikir Terhadap Tingkat Kecemasan Pasien Pre Operasi
Sectio Caesarea Di RSUD Dr. H.

Moch Ansari Saleh Banjarmasin

Hasil uji normalitas

menggunakan Komogorov-Smirnov

data berdistribusi normal $(>0,05)$

sehingga hasil penelitian pada tabel

analisa bivariat dari uji paired sample

t-test didapatkan hasil rata-rata (mean)

sebelum dilakukan terapi zikir yaitu

13,45 dengan standar devisiasi 5.67,

median 13.00 dan sesudah dilakukan terapi zikir didapatkan rata-rata (mean)

9.77 dengan standar devisiasi 4.83, median 8.00.

Maka dapat dilihat nilai selisih mean sebelum dan sesudah dilakukan terapi zikir adalah 3.77 dengan standar devisiasi 0.84 , nilai t 10.032 dan nilai signifikan 0.000 . Sehingga dapat ditarik kesimpulan bahwa terapi zikir berpengaruh terhadap tingkat kecemasan pasien pre operasi sectio caesarea

Pelaksanaan zikrullah yang dilakukan dengan sikap rendah hati dan 
Dinamika Kesehatan Jurnal Kebidanan dan Keperawatan Vol 10 No. 22019 ( ISSN: 2086-3454 EISSN: 2549-4058)

url: http://ojs.dinamikakesehatan.unism.ac.id DOI: https://doi.org/10.33859/dksm.v10i2

Pengaruh Terapi Zikir Terhadap Tingkat Kecemasan Pasien Pre Operasi Sectio Caesarea

Di RSUD Dr. H. Moch. Ansari Saleh Banjarmasin 2018

kushu akan membawa dampak

relaksasi dan ketenangan. Bacaan zikir

yang di ulang - ulang merupakan salah

satu cara untuk memusatkan pikiran

seseorang terhadap makna zikir.

Kalimat zikir sendiri mengandung

makna positif, sehingga pikiran negatif

yang dialami seseorang yang cemas

akan digantikan dengan pikiran positif

ketika orang tersebut berfokus pada

kalimat zikir. Ketika seseorang selalu

mengucapkan kalimat positif maka

kalimat positif diyakini mampu untuk

menghasilkan pikiran serta emosi

positif (Newberg \& Waldman, 2013).

Emosi positif mampu merangsang

kerja limbic untuk menghasilkan

endorphine. Endorphine mampu

menimbulkan perasaan euforia,

bahagia, nyaman, menciptakan

ketenangan dan memperbaiki suasana

hati (mood) seseorang hingga membuat

seseorang berenergi (Suryani, 2013).

Hal yang terkait dengan zikir

dan kecemasan yang dilakukan oleh
Mardiyono dkk (2007) yang meneliti

tentang efek zikir terhadap kecemasan

pasien yang akan dioperasi juga menunjukkan nilai yang signifikan $(\mathrm{p}=$ $<0.05)$.

Selaras dengan penelitian sebelumnya dengan judul yang hampir sama yaitu "Pengaruh berzikir terhadap penurunan tingkat kecemasan pada pasien pre operasi di RS TK III Dr R Soeharsono Banjarmasin 2017" oleh Rahmawati (2017) yang dilakukan di ruang penyakit dalam. Berdasarkan uji $t$ dependen diperoleh nilai signifikasi 0.000 ( $\mathrm{p}$ value $<0,05$ ) dengan nilai selisih 8,73 , nilai t 11,175 dan standar devisiasi 3.300. Sehingga ditarik kesimpulan bahwa ada pengaruh berzikir terhadap tingkat kecemasan pre operasi di RS TK III $\mathrm{Dr} R$ Soeharsono Banjarmasin.

Berdasarkan penjelasan diatas maka peneliti berpendapat bahwa terapi zikir yang dilakukan selama 10 menit secara berulang dengan 
Dinamika Kesehatan Jurnal Kebidanan dan Keperawatan Vol 10 No. 22019 ( ISSN: 2086-3454 EISSN: 2549-4058)

url: http://ojs.dinamikakesehatan.unism.ac.id DOI: https://doi.org/10.33859/dksm.v10i2

Pengaruh Terapi Zikir Terhadap Tingkat Kecemasan Pasien Pre Operasi Sectio Caesarea

Di RSUD Dr. H. Moch. Ansari Saleh Banjarmasin 2018

membaca kalimat tasbih, tahmid dan

takbir masing-masing 33x efektif untuk

menurunkan tingkat kecemasan pasien

pre operasi pasien pre operasi sectio

caesarea di RSUD Dr. H. Moch Ansari

Saleh Banjarmasin.

\section{Simpulan}

1. Hasil identifikasi sebelum dilakukan terapi zikir pada pasien pre operasi Sectio Caesarea Di RSUD Dr. H. Moch Ansari Saleh Banjarmasin tingkat kecemasan rata-rata (mean) 13.54 (kecemasan ringan).

2. Hasil identifikasi sesudah dilakukan terapi zikir pada pasien pre operasi Sectio Caesarea Di RSUD Dr. H. Moch Ansari Saleh Banjarmasin tingkat kecemasan rata-rata (mean) 9.77 (kecemasan ringan).

3. Hasil uji statistik dengan uji paired sample t-test didapatkan hasil $p$ value $=0.000 \leq 0,05$. Sehingga Ho ditolak dan Ha diterima, dengan demikian dapat ditarik kesimpulan ada pengaruh yang signifikan antara Terapi Zikir
Terhadap Tingkat Kecemasan Pasien

Pre Operasi Sectio Caesarea Di RSUD

Dr. H. Moch Ansari Saleh Banjarmasin.

\section{Saran}

1. Bagi Sekolah Tinggi Ilmu Kesehatan Cahaya Bangsa Banjarmasin

Hasil penelitian ini dijadikan sebagai referensi atau bahan pustaka, menambah pengetahuan bagi mahasiswa keperawatan yang dapat diaplikasikan melalui tindakan asuhan keperawatan pada aspek spiritual dalam menghadapi kecemasan pasien pre operasi sectio caesarea ketika mahasiswa terlibat dalam praktek klinik keperawatan maternitas. Bagi mahasiswa lain yang ingin melanjutkan penelitian agar dapat menghilangkan keterbatasan dalam penelitian ini dengan memperhatikan hal yang dapat mempengaruhi seperti vital signt, pengalaman operasi serta menambahkan variabel yang belum diteliti dengan desain penelitian dan 
Dinamika Kesehatan Jurnal Kebidanan dan Keperawatan Vol 10 No. 22019 ( ISSN: 2086-3454 EISSN: 2549-4058)

url: http://ojs.dinamikakesehatan.unism.ac.id DOI: https://doi.org/10.33859/dksm.v10i2

Pengaruh Terapi Zikir Terhadap Tingkat Kecemasan Pasien Pre Operasi Sectio Caesarea

Di RSUD Dr. H. Moch. Ansari Saleh Banjarmasin 2018

tempat penelitian yang berbeda

menggunakan responden yang lebih luas.

2. Bagi RSUD Dr. H. Moch Ansari Saleh

Banjarmasin

Diharapkan kepada pihak

RSUD Dr. H. Moch Ansari Saleh

Banjarmasin untuk dapat menjadikan

terapi zikir ini sebagai tambahan

tindakan asuhan keperawatan pada

aspek spiritual bagi pasien pre operasi

sectio caesarea sehingga pelayanan

yang diberikan tidak hanya berupa

aspek biologis namun juga menyentuh

aspek spiritual.

3. Bagi Responden

Penelitian ini berguna untuk

menambah wawasan dan informasi

yang dapat dibagikan untuk membantu

menurunkan kecemasan para ibu yang

menghadapi persalinan secara operasi

sectio caesarea.

\section{Daftar Pustaka}

Abdillah. 2014. Pengaruh Zikir Terhadap Skor kecemasan Mahasiswa Keperawatan UIN Syarif Hidayatullah Jakarta Menghadapi Ujian Skill-Lab. (http://repository.uinjkt.ac.id/dspace/ handle/123456789/25599) diakses pada hari Sabtu, 10 Maret 2018

Ahsan. 2014. Faktor-Faktor Yang Mempengaruhi Kecemasan Pre Operasi Pada Pasien Sectio Caesarea. (http://ejournal.umm.ac.id/index.php/ keperawatan/article/view/4010) diakses pada hari Sabtu, 10 Maret 2018

Hastuti, Dwi. 2015. Hubungan Pengetahuan Tentang Sectio Caesarea Dengan Kecemasan Ibu Pre Operasi di Ruang Catleya Rumah Sakit Panti Waluyo Surakarta.

(https://scholar.google.co.id/scholar? $\mathrm{q}=$ related:Nxeh4yCvc1gJ:scholar.go ogle.com $/ \&$ scioq $=\& h l=$ en\&as_sdt $=0$ , $5 \&$ as_vis $=1$ ) diakses pada hari Sabtu, 10 Maret 2018

Junita, Nurmala Sari. 2012. Pengaruh Dzikir Terhadap Penurunan Tingkat Kecemasan Pasien Pre Operatif Kanker Serviks. (https://jurnal.usu.ac.id/jkk/article/vie w/327) diakses pada hari Sabtu, 10 Maret 2018

Patimah, Iin. (2015). Pengaruh Relaksasi Zikir Terhadap Tingkat Kecemasan Pasien Gagal Ginjal Kronis Yang Menjalani Hemodialisa.

(http://jkp.fkep.unpad.ac.id/index.php /jkp/article/view/95) diakses pada hari Sabtu, 10 Maret 2018 
Dinamika Kesehatan Jurnal Kebidanan dan Keperawatan Vol 10 No. 22019 ( ISSN: 2086-3454 EISSN: 2549-4058)

url: http://ojs.dinamikakesehatan.unism.ac.id DOI: https://doi.org/10.33859/dksm.v10i2

Pengaruh Terapi Zikir Terhadap Tingkat Kecemasan Pasien Pre Operasi Sectio Caesarea Di RSUD Dr. H. Moch. Ansari Saleh Banjarmasin 2018

Pawatte, I., Pali, C., \& Opod, H. 2013. Perbedaan Tingkat Kecemasan Pada Ibu Pre Sectio Caesarea di RSIA Kasih Ibu dan RSUP. Prof. Dr. RD Kandou Manado. Jurnal Kedokteran Komunitas dan Tropik.

Rahayu Andiyani (2013). Pengaruh Terapi Musik Terhadap Tingkat Kecemasan Pasien Pre Operasi Sectio Caesarea. (http://husadamahakam.poltekkeskaltim.ac.id/ojs/index.php/Home/artic le/view/41) diakses pada hari Sabtu, 10 Maret 2018

RSUD Dr. H. Moch. Ansari Saleh Banjarmasin (2018). Data Persalinan Sectio Caesarea di Ruang Nifas.

Subandi, M. A. (2014). Psikologi Dzikir. Yogyakarta : Pustaka Pelajar

Sugiyono. (2014). Metode Penelitian Pendidikan Pendekatan Kuantitatif, Kualitatif, dan $R \& D$. Bandung: Alfabeta.

Suhaimie, Muhammad Yasin. 2013. Dzikir dan Doa. Malang: Universitas

Suliswati. 2013. Konsep Dasar Keperawatan Kesehatan Jiwa. Jakarta: EGC

Stuart W Gail (2012). Buku Saku Keperawatan Jiwa. Edisi 5 revisi. Jakarta: EGC

Suririnah. (2012). Buku Pintar Kehamilan dan Persalinan. Jakarta : PT. Gramedia Pustaka Utama

Zainul, Zen. (2015). Kekuatan Metode Lafidzi; Hidup Sehat dengan Olah lahir, Fikir, dan Fikir. Jakarta: Duantum Media. 